\title{
Biotechnology in nutrition and food engineering
}

\begin{abstract}
Biotechnology encompasses the basic and applied sciences of living systems and their engineering aspects required to exploit their bioprocesses to bring products to the market place.

While understanding of bioprocess technology has rapidly advanced in recent years, man has been practicing biotechnology since prehistoric times. Today biotechnology has moved beyond local production of alcohol or fermented foods to the production of bio-ingredients and refined products and it has a tremendous potential for further increasing food production, improving food raw materials and producing ingredients that will improve human health.

It should be understood that biotechnology is a collection of techniques some of which may involve genetic engineering for the production of genetically modified foods (GMO).

Since "biotechnology" can include numerous processes and applications, the term "genetically modified" is applied only to products that have been genetically engineered.

Genetically modified foods (GMO) have been hailed by some people as an indispensable tool for solving the world's food problems, and denounced by others as potentially catastrophic dangers on several grounds, including safety issues, and environmental concerns.

Keywords: food biotechnology, food bio ingredients, functional foods, agriculture biotechnology, food enzymes, bioconversion, genetic engineering, genetically modified foods
\end{abstract}

Volume I Issue 5 - 2014

\author{
Osama O Ibrahim,' Donal F Day² \\ 'Consultant Biotechnology/ Food Safety, Bio Innovation, USA \\ ${ }^{2}$ LSU Agricultural Center, USA
}

\author{
Correspondence: Osama O lbrahim, Consultant \\ Biotechnology/ Food Safety, Bio Innovation, 7434 Korbel, Dr. \\ Gurnee IL. 6003I, USA, Tel 8476820655 ,
}

Email bioinnovation04@yahoo.com

Received: July II, 2014 | Published: July II, 2014
Abbreviations: GMO, genetically modified foods; GRAS, generally recognized as safe; FDA, food and drug administration; USDA, united states department of agriculture; EPA, environmental protection agency; APHIS, animal and plant health inspection service

\section{Introduction: historical perspective (Table I)}

Biotechnology refers to the use of living organisms to make useful products, and overlaps with bioengineering and industrial microbiology. ${ }^{1}$

Biotechnology has been unwittingly used for several thousand years, initially in the area of food production and preservation as exemplified by the early production of alcoholic beverages and bread using microbial "contaminants. Our early ancestors used fermentation without knowing the existence of microbial life. Egyptians were brewing beer and producing baked products by the $4^{\text {th }}$ millennium BC. Distillation of ethanol was developed and applied in China in the $2^{\text {nd }}$ millennium.

The modern biotechnology developed from the $19^{\text {th }}$ century after the discovery of microbiology and microbial life. Today, modern fermentation is still based on the principle of combining living matter (microorganisms) with nutrients under controlled conditions to produce high yield of the desired end products.

In the first half of the $20^{\text {th }}$ century World War 1 drove the development of the first large scale fermentation processes outside of alcohol production, the acetone and butanol process for the production of explosives and the citric acid fermentation in response to the disruption of Italian citrus exports.. The pressures of World War 2 brought us antibiotic fermentations in the form of penicillin and then streptomycin.

In the 1980s, recombinant gene technology led to the production of insulin for diabetes, rennet enzyme for cheese production ${ }^{2,3}$ and genetically engineered yeast for baking., ${ }^{4,5}$ These genetically engineered bio ingredients were the first products manufactured using recombinant technology.

Today genetically engineered microorganisms for the production of vitamins, organic acids, amino acids, sweeteners ,edible oils and nutritional supplements can be developed from the insertion of a functional gene ${ }^{6}$ (DNA) into a host such as Lactic acid bacteria ${ }^{7}$ are a Gram positive bacteria present in fermented foods and are identified as Generally Recognized As Safe (GRAS).

These lactic acid bacteria and probiotic microorganisms in fermented foods have been used for many years for health reasons and are now an attractive alternative for treating of intestinal disorders and seem to influence the immune system via stimulating protective immune cells. Through genetic engineering, it is possible to strengthen the effect of existing probiotic. ${ }^{8}$ strains and create completely new probiotics $^{9}$ with multiple health benefits These natural or genetically engineered beneficial bacteria might alter the ratio of "good to bad bacteria "that inhabit the intestine, and might specifically block activity of food borne pathogens to prevent of gastrointestinal diseases.

Biotechnology, including genetic engineering technology, is going to play an important role in the production for functional foods. 
Functional foods also known as Nutraceuticals ${ }^{10}$ are going to be come preventive medicines and might help tackle health related issues For example, it is widely believed that omega- 3 fatty acids are beneficial against cardiovascular diseases.

In addition, genetically engineered technology has resulted in worldwide significant changes in plant ${ }^{11,12}$ and livestock ${ }^{13}$ production that will affect all steps of the production chain from agrochemical inputs and breeding to final food processing.

Because biotechnology process (fermentation) uses living materials, they offer several advantages over conventional chemical process (synthetic chemistry). Biotechnology can use renewable resources as raw materials and can operate at lower temperature, pressure and $\mathrm{pH}$ to produce high yield of end products with less Table I History of biotechnology energy consumption and cost.

In the most of biotechnology processes enzymes in whole microorganisms or extracted from cellular components are used to catalyze the biochemical reactions for the production of desired bioproducts that have applications in food processing, functional foods, food supplements, pharmaceuticals, chemical industry, diagnostics, environmental cleanup, etc.

Enzymes are catalysts that can convert raw materials (substrates) to form desired end products. ${ }^{14}$ These enzymes carry out the bioconversions. Early in the discovery of bioconversion process, three major challenges were present that are resolved by newly developed advanced technologies.

\begin{tabular}{|c|c|}
\hline Year & Discovery \\
\hline $10,000 \mathrm{BC}$ & Wine making developed in Eastern Mediterranean \\
\hline $7,000 \mathrm{BC}$ & Beer developed in Egypt and Babylon \\
\hline $5.000 \mathrm{BC}$ & Cheese making and some medicinal plants were developed \\
\hline $4,000 \mathrm{BC}$ & Vinegar was referenced in old testament \\
\hline $500 \mathrm{AD}$ & Algae was cultivated for food consumption by Aztecs \\
\hline $500 \mathrm{AD}$ & Yogurt, Sauces and fermented foods were developed \\
\hline 1600 & The name fermentation was used \\
\hline 1600 & Van Leeuwenhoek observed yeast cells in alcohol fermentation \\
\hline 1781 & Pressed Baker's yeast produced by Dutch (this is the first improved process) \\
\hline 1789 & Jenner demonstrated ability to confirm the resistance to smallpox infection by vaccination \\
\hline 1837 & $\begin{array}{l}\text { Cagniard-Latour, Schwann and Kutzing independently hypothesized that yeast is a living thing (this is the first } \\
\text { knowledge on cell theory) }\end{array}$ \\
\hline 1847 & $\begin{array}{l}\text { Blondeau studied fermentation of lactic acid, butyric acid, acetic acid and urea. He hypothesized that different } \\
\text { fermentations carried out by different fungi }\end{array}$ \\
\hline 1870 & The first experimental corn hybrid is produced in a laboratory \\
\hline 1875 & $\begin{array}{l}\text { Pasteur demonstrated that living yeast cells ferment sugar into ethanol and carbon dioxide } \\
\text { Pasteur, noted cylindrical organisms produced butyric acid only in the absence of oxygen (this is the first knowledge } \\
\text { on anaerobic fermentation) }\end{array}$ \\
\hline 1859 & Darwin published the Origin of Species \\
\hline 1877 & $\begin{array}{l}\text { Pasteur noted relationship between microorganisms and infection diseases (this is the first knowledge on pathogenic } \\
\text { organisms) }\end{array}$ \\
\hline 1881 & $\begin{array}{l}\text { Koch developed techniques for the handling and maintenance of cultures (this is first modern industrial microbiology } \\
\text { techniques) }\end{array}$ \\
\hline I88I & First commercial production of lactic acid by anaerobic fermentation \\
\hline 1894 & $\begin{array}{l}\text { Takamine patented process to isolate diastase enzyme from mold that break starch (this is the first knowledge on } \\
\text { enzymes and its application) }\end{array}$ \\
\hline 1916 & $\begin{array}{l}\text { Germany produces baker's yeast grown on molasses as protein supplement. Also, produced glycerol by yeast } \\
\text { fermentation }\end{array}$ \\
\hline 1911 & American pathologist Peyton Rous discovers the first cancer -causing virus \\
\hline 1918 & Great Britain produces acetone and butanol by anaerobic fermentation process \\
\hline 1923 & Commercial production of citric acid by surface culture \\
\hline 1929 & $\begin{array}{l}\text { Fleming demonstrated that mold contaminant in a Petri-dish causes bacterial death. This is the first discovery of } \\
\text { antibiotics }\end{array}$ \\
\hline 1933 & Hybrid corn is commercialized \\
\hline \multirow[t]{2}{*}{1934} & Gautheret successfully cultured plant cells \\
\hline & This is the first knowledge on tissue culture \\
\hline 1940 & Florey and Chain isolated penicillin, elucidated its structure and demonstrated its ant-bacterial properties \\
\hline 1940 & $\begin{array}{l}\text { Waxman discovered streptomycin's } \\
\text { This is the first microbial screening method's }\end{array}$ \\
\hline
\end{tabular}


Table continued..

\begin{tabular}{|c|c|}
\hline Year & Discovery \\
\hline \multirow{4}{*}{$1950 \mathrm{~s}$} & The production of Cortisone at the cost of $\$ 200 / \mathrm{g}$ (now it's cost is $\$ 16 / \mathrm{g}$ ) \\
\hline & The production of polio and peruses vaccines \\
\hline & Artificial insemination of livestock is accomplished using frozen semen DNA is made in a test tube for the first time \\
\hline & The first synthetic antibiotic is developed \\
\hline \multirow{2}{*}{$1960 \mathrm{~s}$} & The production of Xanthus gum \\
\hline & The production of alkine protease for detergents industry \\
\hline \multirow{4}{*}{$1970 \mathrm{~s}$} & The discovery of glucose isomerase and the production of high fructose corn syrup (HFCS) as a sweetener \\
\hline & Human growth hormone is synthesized for the first time \\
\hline & Recombinant human insulin is produced for the first time \\
\hline & Kohler and Milstein developed monoclonal antibodies \\
\hline \multirow{9}{*}{$1980 \mathrm{~s}$} & The production of poly (hydroxybutyrate) \\
\hline & The U.S. Supreme Court approves the principle of patenting organisms \\
\hline & Smallpox is globally eradicated following 20 years mass vaccination effort \\
\hline & The first recombinant DNA vaccine for livestock is developed \\
\hline & The first transgenic animals by transferring genes from other animals into mice \\
\hline & The first biotechnology drug , human insulin approved by FDA \\
\hline & Interferon the first anticancer drug produced through biotechnology \\
\hline & The first pest resistant corn (Bt corn ) is produced \\
\hline & The first recombinant vaccine for human (hepatitis $B$ ) is approved by FDA \\
\hline \multirow{10}{*}{$1990 \mathrm{~s}$} & The production of amino acids (lysine, threonine and isoleucine) \\
\hline & The production of antibodies \\
\hline & The production I,2-propandiol \\
\hline & The first successful gene therapy is performed on a 4 years girl suffering from immune disorder \\
\hline & The first breast cancer gene is discovered \\
\hline & FDA approves bovine somatotropin (BST) for milk production increase in dairy cows \\
\hline & Gene associated with Parkinson's disease is discovered \\
\hline & A sheep named Dolly in Scotland becomes the first animal cloned from an adult cell \\
\hline & Diagnostic test for quick identification of BSE and CJD is developed \\
\hline & The first genetically engineered crop is commercialized \\
\hline \multirow{14}{*}{2000 s } & The production I,2-propandiol \\
\hline & The production of xylito.l \\
\hline & The production of hydroxpropanoic acid \\
\hline & Kenya field test for the first biotechnology crop ( virus resistant sweet potato) \\
\hline & FDA approves the first gene target drug for patient with chronic myeloid leukemia \\
\hline & FDA approves the first transgenic rootworm resistant corn \\
\hline & Completes sequencing human genome \\
\hline & UN Food and Agriculture organization endorse biotechnology crops \\
\hline & FDA approves the first antiangiogenic drug for cancer \\
\hline & FDA approves the first recombinant vaccine against human papillomavirus (HPV) \\
\hline & USDA grants the first regulatory approval for a plant made vaccine \\
\hline & FDA approves the first $\mathrm{H} 5 \mathrm{NI}$ vaccine for avian flue \\
\hline & Global biotechnology crops acreage reaches 330 million acres \\
\hline & FDA approves the first genetically engineered animal for the production of rh antithrombine \\
\hline \multirow{3}{*}{$2010 \mathrm{~s}$} & The creation of the first synthetic cell \\
\hline & Advances in 3-D printing technology leading to skin printing \\
\hline & Advances in stem cell technology \\
\hline
\end{tabular}

\section{First challenge}

Maintaining the desired optimum conditions (temperature, pressure, $\mathrm{pH}$, oxygen levels, etc.) for the bioconversion process.

Solution: The development of automated and computerized equipments to assist in maintaining the desired optimum conditions for bioconversion process and monitoring the reactions. These instruments improved the bioconversion efficiency and increased the end-product yield.

\section{Second challenge}

The formation of unwanted impurities during the bioconversion process resulted in difficulties to produce the end- products in pure forms.

Solution: The development of separation and purification techniques for downstream process resulted in methods to economically produce highly pure end-products with higher recoveries. 


\section{Third challenge}

The cost of catalytic enzymes used in the bioconversion process resulting in higher production cost.

Solution: The developments of Immobilized enzymes and cells systems for both continuous and semi-continuous bioconversion process have dramatically reduced the production cost of end products.

\section{Food biotechnology regulation ${ }^{15-18}$}

Food biotechnology is regulated under the same United States laws that govern the health, safety, efficacy and environmental impacts.

Regulatory control on food biotechnology is the responsibility of three federal agencies:

\section{The food and drug administration (FDA)}

Regulates novel substances in foods and feeds on the basis of dietary risk evaluating food safety allergy, and toxicity. The FDA has the right to ban any biotechnology food product that it determines is unsafe.

\section{The United States department of agriculture (USDA)}

Regulates genetically engineered plants under Animal and Plant Health Inspection Service (APHIS), it is assessing the impact of developed genetically engineered plant on the agriculture industry or the meat processing industry. ${ }^{19}$

\section{The environmental protection agency (EPA)}

Evaluates genetically engineered plants for environmental safety and evaluate risk assessments for potential harm to human and animal health. EPA is also, responsible in establishing tolerance and residue levels for pesticides in fruits and vegetables.

\section{Future perspectives of bioprocess industry}

Today, the biotechnology industry has reached a rapid growth phase based on a broad understanding of genomics, proteomic, ${ }^{13}$ bioinformatics, genetic transformation and molecular breading. These technologies are now being transferred to large scale biotechnology operations.

It is expected that genetically engineered hosts, such as insects, stem and plant cells, and transgenic plants or animals sooner or later will reach broader applications in the production of new bioingredients, with applications in both food and pharmaceutical industries.

The use of extreme-thermophilic microbes in recombinant technology will yield unique enzymes active at high temperature as biocatalysts in non-aqueous solutions and broaden the technology platform to produce reservoir of new bio-products with wide applications in medicine, food, agriculture, environment, energy and chemical industries.

Today food biotechnology has a tremendous potential for increasing food production and improving food nutritional value, flavor and texture of food products. In addition, it has the potential for the production of newly food bio ingredients that will improve food processing and producing functional foods as a preventive medicine.
In the future innovations in biotechnology will continue bringing exciting new advances to improve the life of human beings on earth.

\section{Acknowledgements}

None.

\section{Conflict of interest}

Author declares that there is no conflict of interest.

\section{References}

1. http://www.bio.org/

2. Harris TJ, Lowe PA, Lyons A, et al. Molecular cloning and nucleotide sequence of cDNA coding for calf preprochymosin. Nucleic Acids Res. 1982;10(7):2177-2187.

3. Emtage JS, Angal S, Doel MT, et al. Synthesis of calf prochymosin (prorennin) in Escherichia coli. Proc Natl Acad Sci U S A. 1983;80(12):3671-3675.

4. Aldhous P. Genetic engineering. Modified yeast fine for food. Nature. 1990;344(6263):186.

5. Brange J, Ribel U, Hansen JF, et al. Monomeric insulins obtained by protein engineering and their medical implications. Nature. 1988;333(6174):679-682.

6. Kalra EK. Nutraceutical-definition and introduction. AAPS Pharm Sci. 2003;5(3):27-28.

7. Axelsson L, Lindstad G, Naterstad K. Development of an inducible gene expression system for Lactobacillus sakei. Lett Appl Microbiol. 2003;37(2):115-120.

8. Fuller R. Probiotics in human medicine. Gut. 1991;32(4):439-442.

9. Rijkers GT, Bengmark S, Enck P, et al. Guidance for substantiating the evidence for beneficial effects of probiotics: current status and recommendations for future research. J Nutr. 2010;140(3):671S-676S.

10. Robert ECW. Handbook of Nutraceuticals and Functional Foods. 1st ed. CRC Press Taylor \& Francis Group; 2001.

11. Ronald P. Plant genetics, sustainable agriculture and global food security. Genetics. 2011;188(1):11-20.

12. Key S, Ma JK, Drake PM. Genetically modified plants and human health. J R Soc Med. 2008;101(6):290-298.

13. Gaso-Sokac D, Kovac S, Josic D. Use of proteomic methodology in optimizing of processing control of food of animal origin. Food Technol Biotechnol. 2011;49(4):397-412.

14. punkvijay.blogspot.in/2010/10/bioprocess-introduction_1893.html

15. Davison J. GM plants: Science, politics and EC regulations. Plant Science. 2010;178(2):94-98.

16. http://www.eufic.org/article/en/rid/modern-biotechnology-foodbiotechnology-quality/

17. Chassy B, Jason JH, Gijs AK, et al. Nutritional and safety assessments of foods and feeds nutritionally improved through biotechnology. Comprehensive Reviews in Food Science and Food Safety. 2004;3:38-104.

18. Food Biotechnology in the United States: "Science, Regulation and Issues" U.S. Department of State. Retrieved 2006-08-14.

19. http://agribiotech.info/issues/science-and-agricultural-biotechnology. 